\title{
Increase students' engagement in the classroom
}

\author{
${ }^{1}$ Masoom Ahmed, ${ }^{2}$ Fazluz Zaman, ${ }^{3}$ Munshi Samaduzzaman \\ ${ }^{I} \mathrm{PhD}$ Candidate, Glyndwr University, UK \\ ${ }^{2}$ Adjunct lecturer, University of New South Wales, Australia \\ ${ }^{3}$ Adjunct lecturer, University of Liberal Arts Bangladesh, Bangladesh
}

\begin{abstract}
In this study of we investigated student engagements of level 4 statistical analysis module with a specific interest of how to raise the motivation. We used observation to get into root of problems. We implemented some strategies to increase students' involvement in the class room. We are pleased with the results have achieved. After eight weeks of study we noticed that our strategies helped the students to involve more in the class room and they started enjoying learning statistics. We as teachers should consider action as a continuous process in educational context. We could expand our knowledge using observation. We started our class with a warm up task for about 20 minutes. It helped students to relax and they could start focusing on what they are doing. It also creates a friendly environment. After that we gave them a group activity, using games which put groups against each other to help students' to learn.
\end{abstract}

\section{Introduction}

Student engagement has been defined as "involvement in pedagogically active performs, in the classroom or outside, helps to get computable results" (Kuh et al., 2007), and also "the level of students involvement in various activities has linked with learning outcomes." (Krause and Coates, 2008) Similarly, Hu and Kuh (2001) define engagement as "the contribution that students provide result expected learning outcomes".

By way of contrast, other views about engagement as "the way academic establishments try to include and allow students to gather knowledge" (HEFCE, 2008). Kuh (2009) has defined student engagement as "the time and effort students put on which are related with learning outcomes and academic establishments make sure that students are encouraged to participate designed activities (Kuh, 2001, 2003, 2009)"

In this study, students from level 4 statistical analysis module were investigated. The groups we have been observing were made up of 90 students. While teaching, it has been observed that students sometimes not concentrating and also lacking in motivation.

The purpose of the study is to practice effective strategies that we have been observed during our teaching. This study also aims to find out events students like to do and arrange extrinsic motivation or find an intrinsic one. At the same time it would help them to learn in a meaningful and friendly environment.

During observation we found the following characteristics of our students:

- Lack of contribution and engagement

- They talk among themselves at class room

- Irregular in presenting home works/ exercises given

- They do follow the way we advise them to do.

- Lack of motivation.

Sometimes, because of the above reasons it was really follow the scheme of work. We have also observed that students dislike activities and the units are very long. So we thought to integrate various tasks and follow students' reaction.

\section{Literature Review}

Kurt Lewin is considered as the 'father' of Action Reserach (Kemmis \& McTaggert, 1990; ZuberSkerrit, 1992 \& Holter \& Schwartz- Barcott, 1993), started using action research on education instigated by the Science in Education Movement of late nineteenth century in which scientific method was applied to education (Masters, 1995) followed by the UK originated Teacher-Researcher Movement encouraging teaching based on research (McKernan, 1991).

\section{Action Research Model}

Stephen Kemmis has developed a typical model of action research process (see figure 1)

- Initially an empirical attitude is implemented and also understanding of the problem is developed and strategies are set to solve the identified problems. (The general Plan) 
- After that the involvement is carried on. (Action Research Starts)

- During this stage of involvement different forms of relevant observations are collected. (Checking the application through Observation).

- $\quad$ The new involvement strategies are continued and the cycle repeats until adequate understanding about the problem developed. (Reflection and Revision).

The practise is a repeated in nature and carried out to improve deeper understanding about the problem.

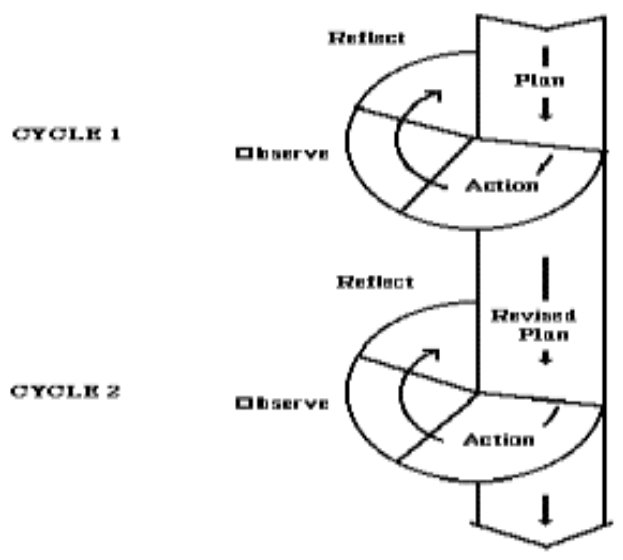

Figure 1: Action Research Model

Source: Dan Maclsaac, (1995)

From our experience in teaching we supported constructivist concept. According to constructivist setting, the students will be given more liberty over their learning. They would be encouraged to take part an active role and self-motivated about learning.

Here teachers have important roles such as goal setting, provide guidelines, resources, support and advices for activities. During this study we tried to focus on how students learn best. Constructivism suggestions different teaching and learning environments than traditional teaching that are basically teachers oriented. Constructivist concept is more of student centered and self-motivated where students learn by doing it.

Constructivism is different from traditional teaching methods, according to Jonassen and Wilson (1999), it offers reality, meaning, learning and knowledge (see Figure 2).

In this study we focus on constructivist and motivation theory which could lead us to better educational environment and students will intrinsically motivated to learn.

Figure 2: Constructivist vs Traditional Methods of Learning

\begin{tabular}{|l|l|l|}
\hline Reality & \multicolumn{1}{|c|}{ Constructivist } & \multicolumn{1}{c|}{ Traditional } \\
\hline Meaning & Product of mind & External to the knower \\
\hline Learning & $\begin{array}{l}\text { Reflects perceptions and } \\
\text { understanding of experiences }\end{array}$ & Reflects external world \\
& $\begin{array}{l}\text { Engaged in cooperative } \\
\text { learning process } \\
\text { Knowledge construction, } \\
\text { interpreting world, } \\
\text { constructing meaning, process- } \\
\text { oriented }\end{array}$ & $\begin{array}{l}\text { External process } \\
\text { Knowledge transmission, } \\
\text { reflecting what teacher } \\
\text { knows, well-structured, } \\
\text { product-oriented }\end{array}$ \\
\hline Knowledge & Constructed & Transmitted \\
\hline
\end{tabular}

Our teaching experience in the field of Business Studies has led us to allow students to self-selected learning materials. Every student has different interest, experience, reading and learning style. Constructivist concept supports and allows this diversity. It also helps to develop individual confidence and interest. 


\section{Observation}

After identifying problems, we tried to change students' attitude towards the tasks given to them. To do that we followed

- Firstly, consider the given tasks and analyse students attitude while doing them

- Secondly, follow if they show any interest doing the task

- Thirdly, find out students preferences based on age and gender

- Finally, analyse students' attitude when doing the work in pairs or groups.

We also followed if they feel comfortable to share information and role played in doing group tasks.

\section{Data Collection Method}

After identifying the problem the following methods of data collection were used to answer the research questions. For action research written evidence is very useful (Grow, 1991). The first method we used for data collection is existing evidence from written resources.

For the collection of written evidence we checked attendance records and the number of tasks completed and submitted by the students. The second method involved in observing and documenting classroom presentations. We have prepared observing and documenting environments over the periods before, during and after participation. A teaching journal is a notebook in which teachers writes teaching experiences (Richards and Farrell, 2005). The journal writing could help the teachers analyse day to day outcomes, attitudes and changes need to take (McDonough).

At first we notes in a teaching journals during each session with a focus on students involvement and enthusiasm. Writing regularly on teaching journal could be helpful for teachers to modify own thinking, explore belief into practice (Farrell, 2007).

When we have started writing teaching journal for the first time, we have reflected on first session teaching practice or experience in the classroom. We tried to write down positive or negative part after each event that caused us to reflect and tried to find out the answer the following questions:

- What did go well

- What did not go well

- What happened after that

- How could we better managed the problem

Next we continued to keep writing the everyday matters, review every week, looking for the developing patterns and reflect on our practice (Richards and Farrell, 2005).

The second period of observation took place during the team building and group activities. An individual might not able to achieve desire outcomes but a group of students could be because group could produce new ideas than individual (Head and Taylor, 1997; Farrel, 2007). When forming the group we considered the following basic four features (Richardson, 1997):

- All group members are safe within the group

- Know what they are aiming for

- Connected with each other

- Show respect to each other

After formation of group we designated group leader, roles are decided for each member.

For observation, we tried to focus on task accomplished and maintaining group cohesion and personal relationship. I also observe and keep notes about each task, commit to attend all activities, involvement and enthusiasm.

Next we used interview for data collection. We used both structured and semi structured interviews focused on participants' perceptions and attitudes towards action research.

At the start of each interview, we explained about the interview in some detail (Bob, 1991). We tried to make clear to the students what use would be made of the data that they are going to provide to me.

To begin the interview, we asked "Tell me about your perception about the module ". We also asked the following questions to the students

- What did enjoy most about today?

- Is there anything that you found less enjoyable?

- Was there anything you did not understand during today's session?

- What other specific comments do you have?

We used attentive listening and kept note of the interviews. 
We developed a questionnaire for the module participants who were involved in this study. We designed the questionnaires considering participants refection about hand-outs, group discussion, activities and how can we involve them more on the module. For close ended questionnaire we used the most widely used scale in survey research Likert Scale.

\section{Data Analysis}

According to Taylor (2002) data analysis starts focusing the collected through questionnaire, interview, observation and notes taken on teaching journal.

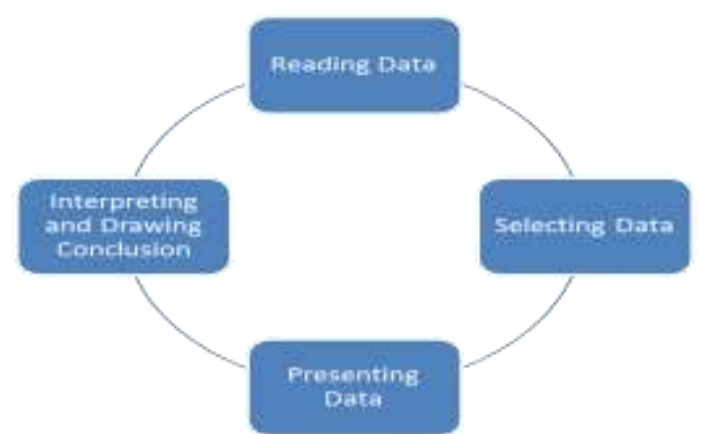

Figure 3: The Constructive Method of Data Analysis

Source: Adopted from Taylor, 2002

We used constructive method of data analysis because of it is more student centred. Data collected from various sources were examined over 8 weeks. This allowed us find out better combination and breakdown of most relevant features of the data.

\section{The actions we have taken are:}

After carefully analysis the data collected we draw some conclusions and create an action to solve the problems identified.

- We observed when students sit with close friends they speak too much with each other and do not concentrate on task.

- We followed that when given them complicated task; they start feeling boring, do not want to complete the exercise and want to take it for home task.

- We noticed that students like working in pairs or groups more than individual.

We tried to maintain the same practice for the class over the study period. At first, we checked the homework. Then explained the theory and covered the topic, ask students if they have any questions. Next step we gave them some exercise based on the topic covered to check understanding.

\section{We found the following outcomes:}

- Students were not motivated may be they not like maths or they might not find the topic interested.

- May be we have to reflect students different learning styles in a meaningful manner.

\section{How can we increase students' engagement in the class room?}

Students are concern about grades and module pre requirements. As a teacher we need to increase students' involvement in the class room to encourage intrinsic motivation which would guide them for future learning.

According to Davis (1993) students like the following elements in the class room:

- A well organised module

- A teacher who is enthusiastic about the learning materials

- A teacher who cares about students interest and learning. class room:

After identifying problems, we have taken the following action plan to motivate my students in the

1. We have given the students few smaller tests rather than giving a large assignment, this would give to learn more manageable and have a chance to improve. We also have given the assessment at beginning of semester,

Given back with feed forward so that students would get chance to make necessary corrections for improvements. 
2. Researches (American Psychology Association, 1992, McMillan, 1991, Lowman, 1984) have revealed that teachers' expectations have a powerful impact on students' motivation. We have increased the difficulty of the assessments and also inform them the intension behind it. We set assessments, given presentation and conducted discussion about it. We have done all of those to make students' to believe that achievement is possible if they do it over the time.

3. According to McKeachie (1999) interaction with peers is an important factor of motivation. We need to create a learning community in the classroom where students would find them as community of learners rather than isolated individual.

4. After identifying the problem, we knew about my students' interests from interview and observation. For example, if we teach marketing module we could ask our student to come out with the idea about starting a new product or service in the market. Where students work in a group and each group try to appear with better ideas than others.

5. Using the same method to each class could become boring for us and for the students to lose interest and motivation. We used change in methods in classes such as given short lectures, case studies, stage a debate etc and noticed that students' involvements improved.

6. Bligh (1971) stated that students are more focused, show better ability and are more supportive to the teaching method when they work in groups. In the class room we tried to avoid individual competition, using games put groups against each other to help students' to learn.

7. Too much anxiety could develop frustration and encourage students give up.

Students have a habit of working harder when they are worried about assessment (Cashin, 1979). That's why we set reasonable goals and expectations for assessments.

8. We have started showing model assessments to students. Showing the example of outstanding or poor assessments help students to understand the expectations and standards expected from them.

9. Research (Cashin 1979; Lucas, 1990) indicates that positive feedback influence student motivation. We tried to let students know the weak sections and also include feed forward to improve and succeed over time.

\section{Final Reflection}

We are pleased with the results have achieved. We used observation to get into root of problems. We implemented some strategies to increase students' involvement in the class room. After eight weeks of study we noticed that our strategies helped the students to involve more in the class room and they started enjoying learning statistics.

We as teachers should consider action as a continuous process in educational context. We could expand our knowledge using observation. We started our class with a warm up task for about 20 minutes. It helped students to relax and they could start focusing on what they are doing. It also creates a friendly environment. After that we gave them a group activity, using games which put groups against each other to help students' to learn.

The following lesson we have learnt from this study:

- Students' involvements helps learning because they learn by doing;

- When we offered them different options we gave them autonomous learning environment;

- This action research also helped us to understand aspects of reality and how to improve students'

involvement in teaching practice.

\section{References:}

[1] Kuh, G.D. (2007) How to Help Students Achieve. Chronicle of Higher Education. 53 (41).

[2] Krause, K. and Coates, H. (2008) Students' Engagement in First-Year University.

[3] Kuh, G.D. (2001). Assessing What Really Matters to Student Learning: Inside the National Survey of Student Engagement. Change, $33(3), 10-17,66$.

[4] HEFCE (2008) Tender for a Study into Student Engagement. Bristol: Higher Education

[5] Kuh, G .D . (2009a) What Student Affairs Professionals Need to Know about Student Engagement . Journal of College Student Development . 50 (6), pp . 683-706.

[6] Kuh, G .D . (2009b) Afterword . In: Harper, S .R . and Quaye, S .J . (eds .) Student Engagement in Higher Education. New York and London: Routledge, pp . 313-318

[7] Kurt L. (1946). "Action Research \& Minority Problems". J. of Social Issues, 2, 34 - 46.

[8] Kemmis S. \& McTaggert R. (1990). The Action Research Planner. Geenlog, Deakin University Press.

[9] Zuber-Skerritt, O. (1992). Professional development in higher education London, UK: Kogan Page.

[10] Holter I.M. \& Schwartz B., D. (1993). Action Research: What is it? How it has been used and how can it be used in nursing? J. of Adv. Nursing, 128, 298-304.

[11] McKernan, J., (1991). Curriculum Action Research. A Handbook of Methods and Resources for the Reflective Practitioner London: Kogan Page

[12] Dan Maclsaac. (1995). An introduction to Action Research. [On-line]. Available:

[13] http://physicsed.buffalostate.edu/danowner/actionrsch.html 
[14] Jonassen, D., Peck, K., \& Wilson, B. (1999). Learning with technology. A constructivist perspective. Upper Saddle River, NJ: Prentice Hall

[15] Grow, G. (1991). Teaching learners to be self-directed. Adult Education Quarterly, 41(3), 125-149.

[16] Richards, J. C., \& Farrell, T. S. C. (2005). Professional development for language teachers. New York: Cambridge University Press.

[17] McDonough, J. (1994). A teacher looks at teachers' diaries. English Language Teaching Journal, 18, 57-65.

[18] Farrell, T. S. C. (2007). Reflective language teaching: From research to practice. London: Continuum Press.

[19] Head, K., \& Taylor, P. (1997). Readings in teacher development. London: Heinemann

[20] Richardson, L. (1997). Fields of play: Constructing an academic life. New Brunswick, NJ: Rutgers University Press.

[21] Bob Dick (1991) Helping groups to be effective: skills, processes and concepts for group facilitation. Chapel Hill, Queensland: Interchange.

[22] Taylor, M.(2002). “Action Research in Workplace Education.” A Handbook for Literacy Instruction, Partnerships in Learning.

[23] American Psychological Association(1992). Learner-Centered Psychological Principles: Guidelines for School Redesign and Reform. Washington, D.C.

[24] McMillan, J. H., and Forsyth, D. R. (1991) "What Theories of Motivation Say About Why Learners Learn." In R. J. Menges and M. D. Svinicki (eds.), College Teaching: From Theory to Practice. New Directions for Teaching and Learning, no. 45. San Francisco: Jossey-Bass.

[25] Lowman, J. (1984). "Mastering the Techniques of Teaching. San Francisco": Jossey-Bass.

[26] McKeachie, W. J. (1986).Teaching Tips. (8th ed.) Lexington, Mass.: Heath, 1986

[27] Bligh, D. A.(1971) What's the Use of Lecturing? Devon, England: Teaching Services Centre, University of Exeter.

[28] Cashin, W. E. (1979) "Motivating Students." Idea Paper, no. 1. Manhattan: Center for Faculty Evaluation and Development in Higher Education, Kansas State University.

[29] Hu, S. and Kuh, G.D. (2001) Being (Dis)Engaged in Educationally Purposeful Activities in Higher Education. New York and London: Routledge, pp. 313-318.

[30] Quigley \& G.; Kuhne (Eds.). Creating practical knowledge through action research: Posing problems, solving problems, and improving daily practice San Francisco, CA : Jossey-Bass.

[31] Engagement. Journal of College Student Development. 50 (6), pp. 683-706.

[32] Simpson, M. \& Tuson, J. (1995). Using observation in small-scale research: A beginner's guide. Edinburgh: SCRE.

[33] Stringer, E.T. (1999). Action research (2nd ed.). Thousand Oaks, CA: Sage. 